\title{
Efficacy of Aliskiren/Hydrochlorothiazide Combination for the Treatment of Hypertension: A Meta-Analytical Approach
}

\author{
Manuel P. Morgado ${ }^{\mathrm{a}, \mathrm{b}, *}$, Sandra A. Rolo ${ }^{\mathrm{b}}$ and Miguel Castelo-Branco ${ }^{\mathrm{a}, \mathrm{b}}$ \\ ${ }^{a}$ Health Sciences Research Centre, University of Beira Interior, Av. Infante D. Henrique, 6200-506 Covilhã, Portugal \\ ${ }^{b}$ Hospital Centre of Cova da Beira, E.P.E.,Quinta do Alvito, 6200-251 Covilhã, Portugal
}

\begin{abstract}
Background: Single-pill combinations of aliskiren/hydrochlorothiazide have recently been approved by the European Medicines Agency for the treatment of hypertension.

Objective: This study aimed to assess the antihypertensive efficacy of aliskiren/hydrochlorothiazide combination in reducing systolic and diastolic blood pressure in hypertensive patients.

Methods: A search in International Pharmaceutical Abstracts, MEDLINE, The Cochrane Library and ISI Web of Knowledge was performed from 2000 to November 2009, to identify randomized, double-blind, clinical trials using aliskiren/hydrochlorothiazide for the treatment of hypertension. Studies were included if they evaluated the antihypertensive efficacy of aliskiren/hydrochlorothiazide in patients with mild or moderate essential hypertension and age $\geq 18$ years. The meta-analytical approach calculated the weighted average reductions of systolic and diastolic blood pressure for each daily dosage combination.

Results: We included 5 clinical trials testing several combinations of aliskiren/hydrochlorothiazide and containing data on 5448 patients. In all studies blood pressure was assessed at inclusion (baseline) and after 8 weeks of therapy. Blood pressure reductions and control rates were significantly $(\mathrm{p}<0.05)$ higher with the aliskiren/hydrochlorothiazide combinations than with placebo and the same doses of aliskiren or hydrochlorothiazide alone. The weighted mean reductions $(\mathrm{mm} \mathrm{Hg})$ from baseline of systolic and diastolic blood pressure for each aliskiren/hydrochlorothiazide combination were: -15.8/$10.3(150 / 25 \mathrm{mg}) ;-15.9 /-11.8(300 / 12.5 \mathrm{mg}) ;-16.9 /-11.6(300 / 25 \mathrm{mg})$. Blood pressure control rates (\%) for the above combinations were, at least, respectively: 43.8, 50.1 and 51.9.
\end{abstract}

Conclusions: Aliskiren/hydrochlorothiazide provided clinically significant additional blood pressure reductions and improved blood pressure control rates over aliskiren or hydrochlorothiazide monotherapy.

Keywords: Aliskiren; aliskiren-hydrochlorothiazide; combination therapy; hypertension; blood pressure; antihypertensives.

\section{INTRODUCTION}

Hypertension is a major risk factor in the development of cardiovascular disease, heart attack and stroke and one of the most important public health problems worldwide due to its high prevalence and deleterious impact on the population in terms of excessive morbidity and mortality. Currently, hypertension is estimated to affect approximately $30 \%$ of the US and European population and 1 billion people worldwide and, as the population ages, this number is expected to increase even further. Moreover, despite advances in treatment of the condition, hypertension control rates continue to be suboptimal in both the US and Europe as only about one third have their blood pressure (BP) reduced to the recommended levels by the $7^{\text {th }}$ Joint National Committee (JNC-7) to under $140 / 90 \mathrm{~mm} \mathrm{Hg}$ for uncomplicated hypertension, and less than $130 / 80 \mathrm{mmHg}$ for those with diabetes mellitus or

*Address correspondence to this author at the Health Sciences Research Centre, University of Beira Interior, Av. Infante D. Henrique, 6200-506 Covilhã, Portugal; Tel: +351 275329072;

Fax: +351 275329099; E-mail: manuelaugustomorgado@gmail.com renal disease [1]. Since monotherapy controls the BP of less than $50 \%$ of treated hypertensive patients $[2,3]$, combination therapy with two or more antihypertensive medications is often required to achieve BP control to recommended levels $[1,4]$. At present, the most widely used antihypertensive combinations involve hydrochlorothiazide (HCTZ) and drugs that block the renin-angiotensin system (RAS), such as angiotensin-converting enzyme inhibitors (ACEIs) and angiotensin receptor blockers (ARBs). Recently a new blocker of the RAS, aliskiren, has been developed and approved by the US Food and Drug Administration (FDA, on $5^{\text {th }}$ March 2007) and by the European Medicines Agency (EMEA, on $22^{\text {nd }}$ August 2007) for the treatment of essential hypertension. Aliskiren is an oral direct renin inhibitor, the ratelimiting enzyme in the production of the end product of the RAS cascade, angiotensin II, a potent vasoactive peptide. Aliskiren is a long-acting antihypertensive (half-life $\approx 40$ hours) and has been shown in several clinical trials to be effective in lowering BP, safe and well tolerated in daily doses of 150 and $300 \mathrm{mg}$ (approved once-daily doses) [5]. In a recent systematic review and meta-analysis of six double- 
blind randomized clinical trials to quantify the systolic and diastolic BP (SBP and DBP) lowering efficacy of aliskiren in the treatment of adults with essential hypertension, the obtained weighted mean differences with $95 \%$ CI were: aliskiren $150 \mathrm{mg},-5.5(-6.5,-4.4) /-3.0(-3.7,-2.3) \mathrm{mm} \mathrm{Hg}$; aliskiren $300 \mathrm{mg},-8.7(-9.7,-7.6) /-5.0(-5.6,-4.3) \mathrm{mm} \mathrm{Hg}$ [5]. In double-blind randomized 8 -week clinical trials, aliskiren/HCTZ combination therapy reduced SBP and DBP from baseline to a significantly greater extent than placebo, aliskiren monotherapy and HCTZ monotherapy $[6,7]$. Aliskiren/HCTZ also produced significant additional SBP and DBP reductions in patients inadequately responsive to 4 weeks' prior treatment with aliskiren or HCTZ alone [6].

Single-pill combinations (SPCs) of aliskiren/HCTZ (150/12.5 mg, 150/25 mg, 300/12.5 mg, 300/25 mg) have recently been approved by the US FDA (18 ${ }^{\text {th }}$ January 2008$)$ and by EMEA $\left(16^{\text {th }}\right.$ January 2009) for the treatment of adults with essential hypertension whose BP is not adequately controlled with aliskiren or HCTZ alone, and as a substitution treatment in patients with hypertension adequately treated by the two individual drugs concomitantly at the equivalent fixed dosage. There have been several reviews published with a general scope of pharmacology, pharmacodynamic and pharmacokinetic profile and clinical studies of aliskiren/HCTZ combination. In this paper, we performed a systematic analysis of the literature and a meta-analytical approach to the available clinical trial data for the various combinations of aliskiren/HCTZ to assess their antihypertensive efficacy in the treatment of mild to moderate hypertension.

The aim of this review was to assess the antihypertensive efficacy and tolerability of the aliskiren/HCTZ combination therapy (as a combination of the individual components or as SPCs) in reducing SBP and DBP in patients with mild to moderate hypertension by using systematic analysis of the literature and meta-analytical approach to combine data from different randomized, double-blind, clinical trials.

\section{MATERIALS AND METHODOLY}

A literature search to identify clinical trials using aliskiren in combination with HCTZ for the treatment of hypertension was conducted on December 2009 to obtain all published study reports that met our inclusion criteria.

\section{Inclusion and Exclusion Criteria}

We included all articles in the literature written in any of the major languages. To be included in our review studies were required to be randomized, double-blind, clinical trials using aliskiren in combination with HCTZ (as a combination of the individual components or as SPCs) for the treatment of hypertension. Additionally, studies were included if they evaluated the antihypertensive efficacy (outcome measure) of aliskiren/HCTZ in patients with mild or moderate essential hypertension (SBP 140-179 mm $\mathrm{Hg}$ and/or DBP 90-109 $\mathrm{mm} \mathrm{Hg}$, as defined in current international guidelines [4]) and patient age $\geq 18$ years. Articles were automatically excluded if their results were not reported or had been presented in forms such as abstracts, letters, or commentaries.

\section{Literature Search Strategy}

We searched the following electronic databases: International Pharmaceutical Abstracts, MEDLINE, The Cochrane Library and ISI Web of Knowledge. Each database was independently searched by 2 reviewers for articles published from 2000 to and including November 30, 2009, using the search terms aliskiren, aliskiren/hydrochlorothiazide, aliskiren-hydrochlorothiazide, aliskiren in combination with hydrochlorothiazide, renin inhibitor. The reviewers selected articles based on the predefined inclusion/exclusion criteria and results were matched. A consensus method was applied to judge any article selection divergences. The rationale for decisions was discussed until reviewers agreed on the final decision. A third author was called to resolve any remaining discrepancies concerning article eligibility.

Selected articles' references and reviews of the subject were hand searched for additional studies that were not obtained through our initial electronic search.

\section{Data Extraction}

The following information was gathered for each clinical trial: author names, year of publication, study design and duration, setting, characteristics of the patients enrolled, sizes of the treatment groups, daily treatment regimens and primary endpoint. Outcomes extracted from articles included mean and variation of SBP and DBP at baseline and final assessments for each group, responder rate (DBP $<90 \mathrm{~mm}$ $\mathrm{Hg}$ or $\geq 10 \mathrm{~mm} \mathrm{Hg}$ reduction from baseline) and $\mathrm{BP}$ control rate $(\mathrm{SBP}<140 \mathrm{~mm} \mathrm{Hg}$ and $\mathrm{DBP}<90 \mathrm{~mm} \mathrm{Hg}$ ). Changes from baseline in plasma renin activity (PRA) and plasma renin concentration (PRC) with aliskiren/HCTZ and with either component alone were also extracted whenever reported, as well as adverse events recorded during the trials. During the data extraction phase, we wrote to corresponding authors of studies to request missing data and clarify study details.

\section{Quality Assessment}

The quality of selected articles was assessed by the same principles used in article selection and data extraction (i.e., 2 independent reviewers), and was based on the Jadad et al. method to measure the risk of bias [8]. Their 3-item quality assessment checklist evaluates the following methodological parameters: controlled trial, random allocation of treatments, double-blind follow-up, dropout rate, intention-to-treat (ITT) analysis and absence of other biases. Quality scores were presented as proportions of the total possible score (i.e., 5) of the quality assessment scale (where $100 \%$ represents the maximum quality). The scores were categorized according to the following criteria: weak $(<60 \%)$, fair $(60 \%)$, good $(80 \%)$, or very good $(100 \%)$.

\section{Analysis Method}

For trials meeting the criteria for inclusion in the analysis, the efficacy of treatment was evaluated via measurements of SBP and DBP at the start of the trial (baseline) and after 8 weeks of therapy. The meta-analytical approach therefore compared the efficacy of each aliskiren/HCTZ dose combination in reducing SBP and DBP over this period of time. The analysis method used was based on calculation of 
the mean BP reduction for a set of aliskiren/HCTZ dose combinations evaluated, by weighting the combined data for the trial size using the following formula: (BP reduction [trial 1] - number of patients [trial 1] $+\ldots+\mathrm{BP}$ reduction [trial $\mathrm{n}$ ] - number of patients [trial $\mathrm{n}$ ])/total number of patients (trial $1+\ldots+$ trial $n)$.

\section{RESULTS}

A completed QUOROM flow chart [9] of the literature search strategy applied and results found is depicted in Fig. (1). Initially, 46 potentially relevant RCTs were identified that appeared to meet the inclusion criteria and were screened for retrieval based on their titles and abstracts. Thirty of those articles were excluded for not evaluating aliskiren in combination with hydrochlorothiazide. The remaining 16 articles were retrieved for full-text review. Eleven of those articles were excluded for the following reasons: two had data that were not extractable [10, 11], three presented excluded study designs [12-14], one enrolled patients with severe hypertension [15], four appeared only in the abstract form [16-19] and one was indexed in MEDLINE in duplicate [20]. Therefore, after exclusion criteria were applied, a total of 5 studies involving a total of 5508 patients were included in this analysis [20-24].

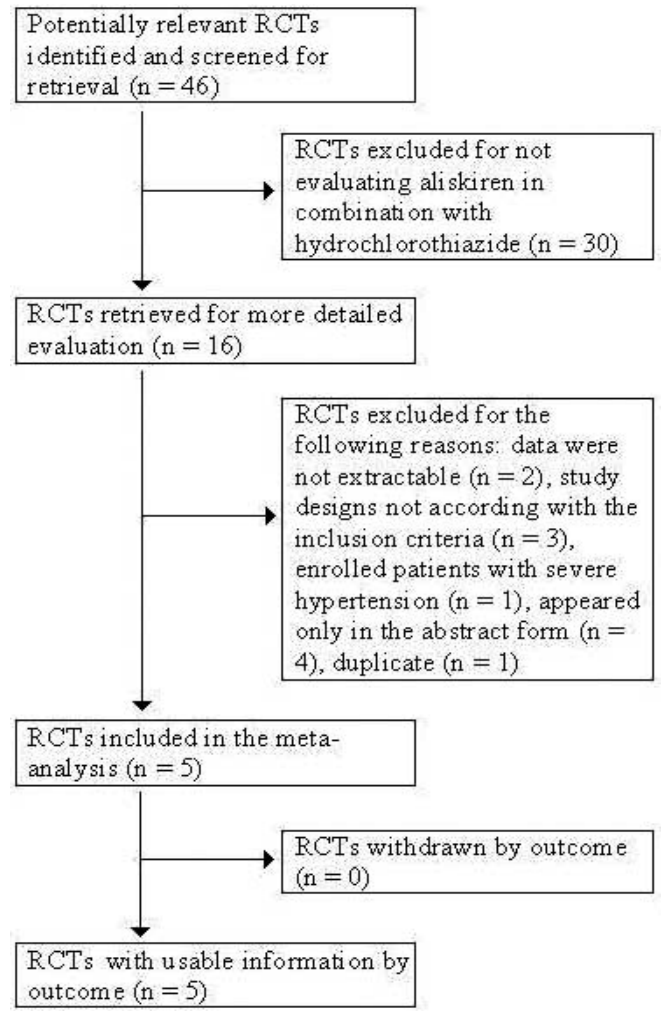

Fig. (1). Quorom flow chart of literature search strategy applied and results. Five double-blind randomized controlled trials met the inclusion criteria, using aliskiren in combination with HCTZ for the treatment of hypertension.

Table 1 presents the overall characteristics of the evaluated studies. The average sample size was $1102 \pm 947$ (mean \pm SD), with a median of 722 and range from 489-2776 patients. All included studies were randomized, double-blind, multicenter clinical trials, proceeded by a single-blind, placebo [21] / active comparator [20, 22-24], run-in period of 2-
4 weeks. Moreover, all five studies specified the change from baseline (start of double-blind treatment) in mean sitting DBP (msDBP) at 8 weeks as the primary endpoint. Secondary efficacy measures included the change in mean sitting SBP (msSBP) [20-24], the proportion of patients with successful response to treatment (defined as msDBP $<90$ $\mathrm{mmHg}$ and/or a $\geq 10 \mathrm{mmHg}$ reduction from baseline) [21, 22] and the proportion of patients attaining BP control (defined as $\mathrm{msDBP}<90 \mathrm{mmHg}$ and $\mathrm{msSBP}<140 \mathrm{~mm} \mathrm{Hg}$ ) [2024]. Two trials used the SPC [21, 22], and three combined the individual components $[20,23,24]$, with aliskiren and HCTZ administered orally as single daily doses in all studies. One trial enrolled obese hypertensive patients only (obesity defined as body mass index of $\geq 30 \mathrm{~kg} / \mathrm{m}^{2}$ ) [22], although in the remaining four trials subgroups of patients with obesity were also present. In the five included clinical trials patient demographics and baseline characteristics were similar across treatment groups. Brief details of the characteristics of each individual trial and treatment group, including mean patient ages, sex ratios, body mass index / obesity and baseline SBP and DBP are provided in Appendix. The average quality score of study reporting was $84 \% \pm 22 \%$ (range 60-100\%), which could be categorized as very good. One study failed to report all information on data variability [21], which prevented the use of an approximation for standard error of the mean (SEM) or confidence interval (CI) estimation, when calculating some weighted average reductions in SBP and DBP. We contacted the corresponding author of this study by email to request missing data on SEM as well as on BP control rate at endpoint for each aliskiren/HCTZ, aliskiren and HCTZ daily doses tested, but no response was provided.

Table 2 details results from clinical trials on the efficacy of aliskiren/HCTZ in reducing BP. In the only placebocontrolled study (and also the largest of the RCTs), aliskiren/HCTZ combination reduced SBP and DBP from baseline to a significantly $(\mathrm{p} \leq 0.0001)$ greater extent than placebo in patients with mild to moderate hypertension [21], furthermore, aliskiren/HCTZ combination (at all but the $75 / 12.5 \mathrm{mg}$ and $150 / 6.25 \mathrm{mg}$ dosages, both of which are not commercially available) decreased SBP and DBP from baseline to a significantly $(p<0.05)$ greater extent than the component monotherapies [21]. In the other selected RCTs, all of which with an active comparator and a non-responder study design [20, 22-24], aliskiren/HCTZ combination was an effective treatment option, producing significantly additional reductions in SBP and DBP in patients with mild to moderate hypertension inadequately responsive to 4 weeks' prior treatment with aliskiren [20] or HCTZ [22-24] alone. In the five included RCTs, BP control rates were also significantly higher with all aliskiren/HCTZ combinations commercially available than with placebo, aliskiren alone and HCTZ alone. One of the included studies did not report the BP response rate [24], in the remaining four studies, BP response rates were also significantly higher with all aliskiren/HCTZ combinations commercially available than with placebo; however, only the three higher dosages of aliskiren/HCTZ combinations yielded significantly higher BP response rates than the component monotherapies [20-23]. Two studies also compared the efficacy of aliskiren/HCTZ 300/25 mg combination in reducing and controlling BP with other treatment 
Table 1. Published Clinical Trials of Aliskiren/HCTZ for Treatment of Mild to Moderate Hypertension

\begin{tabular}{|c|c|c|c|c|c|}
\hline $\begin{array}{l}\text { Reference } \\
\text { (Year) }\end{array}$ & $\begin{array}{l}\text { Study Design, } \\
\text { Duration, Setting, } \\
\text { BP measurement, } \\
\text { No of patients }\end{array}$ & $\begin{array}{l}\text { Demographics and Baseline } \\
\text { Characteristics }^{\mathrm{a}}\end{array}$ & Daily Treatment Regimens & Primary End Point & $\begin{array}{l}\text { Quality } \\
\text { Score }^{\mathrm{b}}\end{array}$ \\
\hline $\begin{array}{l}\text { Villamil } \\
\text { (2007) [21] }\end{array}$ & $\begin{array}{l}\text { Randomized, } \\
\text { double-blind, } \\
\text { placebo-controlled, } \\
\text { multicenter; } 8 \text { wks; } \\
\text { clinic; trough BP; } \\
\mathrm{n}=2776\end{array}$ & $\begin{array}{l}\text { Age } \geq 18 \text { yrs. Eligibility for single-blind } \\
\text { phase: } \mathrm{msDBP} \geq 95 \text { and }<110 \mathrm{mmHg} \\
\text { (baseline). Eligibility for double-blind } \\
\text { phase: } \mathrm{msDBP} \geq 95 \text { and }<110 \mathrm{mmHg} \text { after } 2 \\
\text { or } 4 \text { wks on placebo. Mean age } 55 \mathrm{yrs} ; 55 \% \\
\text { men; } 86 \% \text { Caucasian. }\end{array}$ & $\begin{array}{l}\text { Single-blind, placebo run-in period ( } 2 \text { wks or } 4 \\
\text { wks): Placebo. } \\
\text { Double-blind treatment ( } 8 \text { wks): Placebo; } \\
\text { Aliskiren } 75,150,300 \mathrm{mg} \text {; } \\
\text { HCTZ } 6.25,12.5,25 \mathrm{mg} \text {; } \\
\text { Aliskiren/HCTZ 75/6.25, 75/12.5, 75/25, 150/6.25, } \\
\text { 150/12.5, 150/25, 300/12.5, 300/25mg. }\end{array}$ & $\begin{array}{l}\text { Change in msDBP from } \\
\text { baseline (start } \\
\text { of double-blind } \\
\text { treatment) to wk } 8 \\
\text { endpoint (aliskiren } \\
\text { monotherapy vs } \\
\text { placebo; combination } \\
\text { therapy vs respective } \\
\text { monotherapies) }\end{array}$ & $60 \%{ }^{\mathrm{c}}$ \\
\hline $\begin{array}{l}\text { Jordan } \\
\text { (2007) [22] }\end{array}$ & $\begin{array}{l}\text { Randomized, } \\
\text { double-blind, } \\
\text { multicenter; } 12 \\
\text { wks; clinic; trough } \\
\text { BP; } n=489\end{array}$ & $\begin{array}{l}\text { Age } \geq 18 \text { yrs. Eligibility for single-blind } \\
\text { phase: } \mathrm{msDBP} \geq 95 \text { and }<110 \mathrm{mmHg} \\
\text { (baseline). Eligibility for double-blind } \\
\text { phase: } \mathrm{msDBP} \geq 90 \text { and }<110 \mathrm{mmHg} \text {. BMI } \\
\geq 30 \mathrm{~kg} / \mathrm{m}^{2} \text {; Mean age } 54 \mathrm{yrs} ; 44 \% \mathrm{men} \text {; } \\
99.6 \% \text { Caucasian. }\end{array}$ & $\begin{array}{l}\text { Single-blind treatment ( } 4 \text { wks): HCTZ } 25 \mathrm{mg} \text {. } \\
\text { Double-blind treatment (first } 4 \text { wks - next } 8 \text { wks): } \\
\text { Placebo-HCTZ } 25 \text { - 25mg; } \\
\text { Aliskiren/HCTZ 150/25 - 300/25mg; } \\
\text { Irbesartan/HCTZ 150/25 - 300/25 mg; } \\
\text { Amlodipine/HCTZ 5/25 - 10/25mg; }\end{array}$ & $\begin{array}{l}\text { Change in msDBP from } \\
\text { baseline (start of } \\
\text { double-blind treatment) } \\
\text { to wk } 8 \text { endpoint } \\
\text { (aliskiren/HCTZ 300/25 } \\
\text { mg vs placebo-HCTZ } \\
25 \mathrm{mg} \text { ) }\end{array}$ & $100 \%$ \\
\hline $\begin{array}{l}\text { Nickenig } \\
(2008)[20]\end{array}$ & $\begin{array}{l}\text { Randomized, } \\
\text { double-blind, } \\
\text { multicenter; } 8 \text { wks; } \\
\text { clinic; trough BP; } \\
\mathrm{n}=880\end{array}$ & $\begin{array}{l}\text { Age } \geq 18 \text { yrs. Eligibility for single-blind } \\
\text { phase: } \mathrm{msDBP} \geq 95 \text { and }<110 \mathrm{mmHg} \text { or } \\
\mathrm{msDBP} \geq 85 \text { and }<110 \mathrm{mmHg} \text { if treated for } \\
\text { HT within the } 4 \text { wks prior to screening } \\
\text { (baseline). Eligibility for double-blind } \\
\text { phase: } \mathrm{msDBP} \geq 90 \text { and }<110 \mathrm{mmHg} \text { after } 4 \\
\text { wks of aliskiren } 300 \mathrm{mg} \text { monotherapy. } \\
\text { Mean age } 55 \mathrm{yrs} ; 55 \% \text { men; } 83 \% \text { Caucasian. }\end{array}$ & $\begin{array}{l}\text { Single-blind treatment ( } 4 \mathrm{wks}) \text { : Aliskiren } 300 \mathrm{mg} \text {. } \\
\text { Double-blind treatment ( } 8 \mathrm{wks}) \text { : } \\
\text { Aliskiren } 300 \mathrm{mg} \text {; } \\
\text { Aliskiren/HCTZ 300/12.5, 300/25mg. }\end{array}$ & $\begin{array}{l}\text { Change in msDBP from } \\
\text { baseline (start } \\
\text { of double-blind } \\
\text { treatment) to wk } 8 \\
\text { endpoint (aliskiren } \\
\text { monotherapy vs } \\
\text { combination therapy) }\end{array}$ & $100 \%$ \\
\hline $\begin{array}{l}\text { Blumenstein } \\
\text { (2009) [23] }\end{array}$ & $\begin{array}{l}\text { Randomized, } \\
\text { double-blind, } \\
\text { multicenter; } 8 \text { wks; } \\
\text { clinic; trough BP; } \\
\mathrm{n}=722\end{array}$ & $\begin{array}{l}\text { Age } \geq 18 \text { yrs. Eligibility for single- } \\
\text { blind phase: patients with HT, who were } \\
\text { newly diagnosed, untreated or treated at } \\
\text { the time of screening. Newly diagnosed pts } \\
\text { or pts who had not been treated for HT in } \\
\text { the } 4 \text { wks prior to screening had to have } \\
\text { msDBP } \geq 95 \text { and }<110 \mathrm{mmHg} \text { at the } \\
\text { time of the screening. Eligibility for } \\
\text { double-blind phase: msDBP } \geq 90 \text { and } \\
<110 \text { mmHg after } 4 \text { wks of HCTZ } \\
25 \mathrm{mg} \text { monotherapy. Mean age } 54 \text { yrs; } \\
59 \% \text { men; } 91 \% \text { Caucasian. }\end{array}$ & $\begin{array}{l}\text { Single-blind treatment ( } 4 \text { wks): HCTZ } 25 \mathrm{mg} \text {. } \\
\text { Double-blind treatment ( } 8 \mathrm{wks}) \text { : } \\
\text { HCTZ } 25 \mathrm{mg} \text {; } \\
\text { Aliskiren/HCTZ 150/25, 300/25mg. }\end{array}$ & $\begin{array}{l}\text { Change in msDBP from } \\
\text { baseline (start } \\
\text { of double-blind } \\
\text { treatment) to wk } 8 \\
\text { endpoint (HCTZ } \\
\text { monotherapy vs } \\
\text { combination therapy) }\end{array}$ & $100 \%$ \\
\hline $\begin{array}{l}\text { Geiger } \\
(2009)[24]\end{array}$ & $\begin{array}{l}\text { Randomized, } \\
\text { double-blind, } \\
\text { multicenter; } 8 \text { wks; } \\
\text { clinic; trough BP; } \\
\mathrm{n}=641\end{array}$ & $\begin{array}{l}\text { Age } \geq 18 \text { yrs. Eligibility for single-blind } \\
\text { phase: pts with mild to moderate HT taking } \\
\text { antihypertensive agents. } \\
\text { Eligibility for double-blind phase: msDBP } \\
\geq 95 \text { and }<110 \text { mmHg after } 4 \text { wks of HCTZ } \\
\text { monotherapy. Mean age } 53 \text { yrs; } 57 \% \text { men; } \\
86 \% \text { Caucasian. }\end{array}$ & $\begin{array}{l}\text { Single-blind treatment ( } 4 \mathrm{wks} \text { ): HCTZ } 12.5 \mathrm{mg} \text { for } \\
1 \mathrm{wk} \text { followed by HCTZ } 25 \mathrm{mg} \text { for } 3 \mathrm{wks} \text {. } \\
\text { Double-blind treatment ( } 8 \mathrm{wks} \text { ): HCTZ } 25 \mathrm{mg} \text {; } \\
\text { Aliskiren/HCTZ } 150 / 25 \mathrm{mg} \text { for } 4 \mathrm{wks} \text { followed by } \\
\text { 300/25mg for another } 4 \mathrm{wks} \text {; } \\
\text { Valsartan/HCTZ } 160 / 25 \mathrm{mg} \text { for } 4 \text { wks followed by } \\
320 / 25 \mathrm{mg} \text { for another } 4 \mathrm{wks} \text {; } \\
\text { Aliskiren/Valsartan/HCTZ } 150 / 160 / 25 \mathrm{mg} \text { for } 4 \\
\text { wks followed by } 300 / 320 / 25 \mathrm{mg} \text { for another } 4 \mathrm{wks} \text {. }\end{array}$ & $\begin{array}{l}\text { Change in msDBP from } \\
\text { baseline (start } \\
\text { of double-blind } \\
\text { treatment) to wk } 8 \\
\text { endpoint } \\
\text { (aliskiren/HCTZ } \\
\text { and valsartan/HCTZ } \\
\text { vs aliskiren/valsartan/ } \\
\text { HCTZ) }\end{array}$ & $60 \%^{\mathrm{d}}$ \\
\hline
\end{tabular}

${ }^{\mathrm{a}}$ In each published clinical trial, patient baseline and demographic characteristics were comparable for all treatment groups.

${ }^{\mathrm{b}}$ The percentage of the total possible score (i.e., 5) of the quality assessment scale applied (100\% represents the maximum quality).

${ }^{c}$ Method to generate the sequence of randomization and method of double blind were not described; additionally, some information on outcome variability was not provided.

${ }^{\mathrm{d}}$ Method to generate the sequence of randomization and method of double blind were not described.

BP; blood pressure; HCTZ - hydrochlorothiazide; HT - hypertension; msDBP - mean sitting diastolic blood pressure; pts - patients; wk - week. 
Table 2. Clinical Trial Data on the Efficacy of Aliskiren/HCTZ in Reducing BP

\begin{tabular}{|c|c|c|c|c|c|c|}
\hline Reference & $\begin{array}{l}\text { Patients, } \\
\text { n (ITT) }\end{array}$ & Treatment and Daily Dose (mg) & $\begin{array}{l}\text { Change in SBP from } \\
\text { Baseline at Endpoint } \\
(\mathrm{mm} \mathrm{Hg})\end{array}$ & $\begin{array}{l}\text { Change in DBP from } \\
\text { Baseline at Endpoint } \\
(\mathrm{mm} \mathrm{Hg})\end{array}$ & $\begin{array}{l}\text { Responder } \\
\text { Rate }(\%)\end{array}$ & $\begin{array}{l}\text { BP Control Rate } \\
\text { at Endpoint }(\%)\end{array}$ \\
\hline \multirow{10}{*}{$\begin{array}{l}\text { Villamil } \\
\text { (2007) [21] }\end{array}$} & 183 & Aliskiren 75 & -9.4 & $-8.7 \pm 0.59^{\mathrm{a}}$ & 51.9 & $(29.0$ \\
\hline & 183 & Aliskiren 150 & $-12.2^{\mathrm{b}}$ & $-8.9 \pm 0.59^{\mathrm{a}}$ & 51.9 & to \\
\hline & 194 & HCTZ 6.25 & $-11.0^{\mathrm{a}}$ & $-9.1 \pm 0.58^{\mathrm{a}}$ & 53.6 & $(32.5$ \\
\hline & 188 & HCTZ 12.5 & $-13.9^{c}$ & $-10.1 \pm 0.59^{c}$ & $60.6^{\mathrm{a}}$ & to \\
\hline & 173 & HCTZ 25 & $-14.3^{c}$ & $-9.4 \pm 0.61^{\mathrm{a}}$ & $59.0^{\mathrm{a}}$ & $37.8)$ \\
\hline & 187 & Aliskiren/HCTZ 75/6.25 & $-14.3 \pm 0.93^{\mathrm{c}, \mathrm{d}}$ & $-10.8^{\mathrm{c}, \mathrm{d}}$ & $61.5^{\mathrm{a}}$ & a \\
\hline & 189 & Aliskiren/HCTZ 75/12.5 & $-15.6^{\mathrm{c}}$ & $-11.1^{\mathrm{c}}$ & $63.5^{\mathrm{b}}$ & a \\
\hline & 187 & Aliskiren/HCTZ 150/25 & $-19.5^{\mathrm{c}, \mathrm{d}}$ & $-12.7^{\mathrm{c}, \mathrm{d}}$ & $71.1^{\mathrm{cdd}}$ & $\mathrm{a,d}$ \\
\hline & 180 & Aliskiren/HCTZ 300/12.5 & $-19.8^{\mathrm{c}, \mathrm{d}}$ & $-13.9^{\mathrm{c}, \mathrm{d}}$ & $80.6^{\mathrm{c}, \mathrm{d}}$ & $\mathrm{a,d}$ \\
\hline & 173 & Aliskiren/HCTZ 300/25 & $-21.2 \pm 0.97^{\mathrm{c}, \mathrm{d}}$ & $-14.3 \pm 0.61^{\mathrm{c}, \mathrm{d}}$ & $76.9^{\mathrm{c}, \mathrm{d}}$ & $\mathrm{a}, \mathrm{d}$ \\
\hline \multirow{4}{*}{$\begin{array}{l}\text { Jordan } \\
\text { (2007) [22] }\end{array}$} & 117 & HCTZ 25 & $-8.6 \pm 1.00$ & $-7.9 \pm 0.73$ & 59.0 & 34.2 \\
\hline & 113 & Aliskiren/HCTZ 300/25 & $-15.8 \pm 1.01^{\mathrm{e}}$ & $-11.9 \pm 0.74^{\mathrm{e}}$ & $73.5^{\mathrm{f}}$ & $56.6^{\mathrm{g}}$ \\
\hline & 117 & Irbesartan/HCTZ 300/25 & $-15.4 \pm 1.00^{\mathrm{h}}$ & $-11.3 \pm 0.72^{\mathrm{h}}$ & $70.9^{\mathrm{h}}$ & $54.7^{\mathrm{h}}$ \\
\hline & 122 & Amlodipine/HCTZ 10/25 & $-13.6 \pm 0.98^{\mathrm{h}}$ & $-10.3 \pm 0.71^{\mathrm{h}}$ & $68.0^{\mathrm{h}}$ & $45.1^{\mathrm{i}}$ \\
\hline $\begin{array}{l}\text { Nickenig } \\
(2008)[20]\end{array}$ & 296 & Aliskiren 300 & $-8.0 \pm 0.9$ & $-7.4 \pm 0.5$ & 62.2 & 40.9 \\
\hline \multirow{4}{*}{$\begin{array}{l}\text { Geiger } \\
(2009) \text { [24] }\end{array}$} & 151 & HCTZ 25 & $-6 \pm 1.12$ & $-6 \pm 0.70$ & NR & 20.53 \\
\hline & 164 & Aliskiren/HCTZ 300/25 & $-15 \pm 1.08^{1}$ & $-11 \pm 0.67^{1}$ & NR & $40.85^{1}$ \\
\hline & 154 & Valsartan/HCTZ 320/25 & $-18 \pm 1.12^{1}$ & $-14 \pm 0.70^{1}$ & NR & $48.70^{1}$ \\
\hline & 168 & Aliskiren/Valsartan/HCTZ 300/320/25 & $-22 \pm 1.07^{1, p, q}$ & $-16 \pm 0.67^{1, p, q}$ & NR & $66.67^{1, \mathrm{p}, \mathrm{r}}$ \\
\hline
\end{tabular}

Changes in blood pressure are presented as the least-squares mean changes (with $\pm \mathrm{SEM}$, whenever provided by the authors).

${ }^{\mathrm{a}} \mathrm{P}<0.05,{ }^{\mathrm{b}} \mathrm{P}<0.001,{ }^{\mathrm{c}} \mathrm{P} \leq 0.0001 \mathrm{vs}$ placebo; ${ }^{\mathrm{d}} \mathrm{P}<0.05$ vs each component monotherapy; ${ }^{\mathrm{e}} \mathrm{P}<0.0001 \mathrm{vs} \mathrm{HCTZ} 25 \mathrm{mg} ;{ }^{\mathrm{f}} \mathrm{P}<0.05 \mathrm{vs} \mathrm{HCTZ} 25 \mathrm{mg} ;{ }^{\mathrm{g}} \mathrm{P}=0.0005$ vs HCTZ $25 \mathrm{mg} ;{ }^{\mathrm{h}} \mathrm{P}>$ 0.05 vs aliskiren/HCTZ $300 / 25 \mathrm{mg} ;{ }^{\mathrm{i}} \mathrm{P}=0.052 \mathrm{vs}$ aliskiren/HCTZ $300 / 25 \mathrm{mg} ;{ }^{j} \mathrm{P}<0.001 \mathrm{vs}$ aliskiren $300 \mathrm{mg} ;{ }^{\mathrm{k}} \mathrm{P}=0.002 \mathrm{vs}$ aliskiren $300 \mathrm{mg} ;{ }^{\mathrm{l}} \mathrm{P}<0.001 \mathrm{vs} \mathrm{HCTZ} 25 \mathrm{mg} ;{ }^{\mathrm{m}} \mathrm{P}=0.009$ vs aliskiren/HCTZ 150/25 mg; ${ }^{\mathrm{n}} \mathrm{P}<0.001 \mathrm{vs}$ aliskiren/HCTZ $150 / 25 \mathrm{mg} ;{ }^{\circ} \mathrm{P}=0.033 \mathrm{vs}$ aliskiren/HCTZ $150 / 25 \mathrm{mg} ;{ }^{\mathrm{p}} \mathrm{P}<0.001 \mathrm{vs}$ aliskiren/HCTZ $300 / 25 \mathrm{mg}$; ${ }^{\mathrm{q}} \mathrm{P}<0.01 \mathrm{vs}$ valsar$\tan /$ HCTZ 320/25 mg; ${ }^{\mathrm{r}} \mathrm{P}<0.001$ vs valsartan/HCTZ 320/25 mg.

BP - Blood pressure; DBP - Diastolic blood pressure; HCTZ - Hydrochlorothiazide; ITT - Intention-to-treat analysis; NR - Not reported; SBP - Systolic blood pressure.

combinations (amlodipine/HCTZ 10/25 mg, irbesartan/ HCTZ 300/25 mg, valsartan/HCTZ 320/25 mg and aliskiren/ valsartan/HCTZ $300 / 320 / 25 \mathrm{mg}$ ) [22, 24]. Only the last combination yielded significantly greater decreases in SBP and DBP and higher BP control rates than the aliskiren/ HCTZ 300/25 mg combination [24].

Table 3 presents the weighted mean reductions from baseline of SBP and DBP and BP control rate for each aliskiren/HCTZ combination commercially available. It should be noted that four RCTs were not placebo-controlled and, furthermore, the active comparator (aliskiren or HCTZ) differed in these studies [20, 22-24]. In these circumstances, appraisal of the change from baseline in SBP and DBP achieved by each aliskiren/HCTZ combination allows some appreciation of their antihypertensive efficacy since all data are derived from studies of similar design. Nevertheless, the higher BP reductions reported in the Villamil (2007) trial [21] with aliskiren/HCTZ (a fact also observed with aliskiren and HCTZ monotherapies) must be observed with some caution, as they clearly diverged upward from the results 
Table 3. Weighted Average Reductions From Baseline of SBP and DBP and BP Control Rate for Each Aliskiren/HCTZ Combination Commercially Available

\begin{tabular}{|l|l|l|l|l|l|}
\hline $\begin{array}{l}\text { Aliskiren/HCTZ } \\
\text { Combination Evaluated }\end{array}$ & $\begin{array}{l}\text { Number of } \\
\text { Clinical Trials }\end{array}$ & $\begin{array}{l}\text { Total number } \\
\text { of Patients }\end{array}$ & $\begin{array}{l}\text { Change in SBP from Baseline } \\
\text { at Endpoint (mm Hg) }\end{array}$ & $\begin{array}{l}\text { Change in DBP from Baseline } \\
\text { at Endpoint (mm Hg) }\end{array}$ & $\begin{array}{l}\text { BP Control } \\
\text { Rate }(\%)^{\mathrm{a}}\end{array}$ \\
\hline \hline Aliskiren/HCTZ 150/12.5 mg & 1 & 184 & -17.6 & -11.9 & {$[37.4,59.5]^{\mathrm{a}}$} \\
\hline Aliskiren/HCTZ 150/25 mg & 2 & 429 & -15.8 & -10.3 & -11.8 \\
\hline Aliskiren/HCTZ 300/12.5 mg & 2 & 472 & -15.9 & $-11.6 \pm 0.3$ & {$[43.8,53.5]^{\mathrm{a}}$} \\
\hline Aliskiren/HCTZ 300/25 mg & 5 & 966 & $-16.9 \pm 0.4$ & {$[50.1,58.5]^{\mathrm{a}}$} \\
\hline
\end{tabular}

Changes in blood pressure are presented as the weighted least-squares mean changes \pm SEM (not all variability information was provided in the trial of Villamil (2007) [21], preventing the use of an approximation for SEM or confidence intervals estimation for the first three aliskiren/HCTZ dose combinations).

${ }^{a}$ The range presented is due to the trial of Villamil (2007) [21], which presented the range of BP control rate for aliskiren/HCTZ combination, without specify the values for each dose combination.

BP - Blood pressure; DBP - Diastolic blood pressure; HCTZ - Hydrochlorothiazide; SBP - Systolic blood pressure.

obtained by other authors and yielded an unexpected higher effect of the lowest dose of aliskiren/HCTZ commercially available $(150 / 12.5 \mathrm{mg})$.

Some authors also studied changes from pre-treatment [22] (start of single-blind treatment) or baseline [21, 24] (start of double-blind treatment) in PRA and PRC with aliskiren and HCTZ monotherapy and combination therapy. Aliskiren 75, 150 and $300 \mathrm{mg} /$ day decreased (the geometric) PRA from baseline by $54.2 \%, 65.1 \%$ and $57.6 \%$, respectively [21]. Conversely, HCTZ monotherapy significantly increased PRA at 12.5 and $25 \mathrm{mg}$ /day dosages [21, 22]. When combined, aliskiren/HCTZ significantly reduced PRA from pretreatment (by 45\%) [22] and baseline (by 40.5$62.3 \%)$ [21, 24], whereas combined treatment with amlodipine/HCTZ, irbesartan/HCTZ and valsartan/HCTZ significantly increased PRA [22, 24]. Aliskiren elevated PRC from baseline in a dose-dependent manner, with increases of $164 \%, 192 \%$ and $348 \%$ at dosages of 75,150 and 300 $\mathrm{mg}$ /day, respectively [21]. HCTZ $25 \mathrm{mg}$ /day increased PRC by $108 \%$, whereas lower dosages did not cause alterations in PRC that significantly differed from placebo. All aliskiren/ HCTZ combinations significantly increased PRC [21, 24], the magnitude of increases was related to the dosages of both components, with the most marked increase $(1211 \%$ from baseline) occurring in the aliskiren/HCTZ 300/25 mg group [21]. Furthermore, increases in PRC in several combination groups were considerably greater than the sum of the increases seen with each component [21]. It should be noted that Geiger et al. measured the baseline PRA and PRC at the end of the 4-week single-blind HCTZ period [24]. Therefore, the effect of HCTZ on PRA and PRC might have been stabilized with this initial therapy and no further changes after the 8-week additional HCTZ treatment was observed [24].

Each published study also describes the most common adverse events reported in the clinical trials. Aliskiren/ HCTZ, as a SPC or as a combination of the individual components concurrently administered, was generally well tolerated in the five clinical trials reviewed. The majority of adverse events were mild and transient in nature, with the most commonly reported events including nasopharyngitis [20-24], headache [20-24], dizziness [22, 23], back pain [23], vertigo [23] and hypercholesterolemia [20]. The proportion of patients experiencing hypokalaemia (defined as serum potassium levels $<3.5 \mathrm{mmol} / \mathrm{L}$ ) were numerically lower with aliskiren/HCTZ than with HCTZ alone [21, 23, 24]. The proportion of patients with hypokalemia was also lower in the aliskiren/HCTZ 300/12.5 mg group (0.4\%) and aliskiren $300 \mathrm{mg}$ monotherapy group $(0.4 \%)$ than in the aliskiren/ HCTZ 300/25 mg group (2.5\%) [20]. In obese hypertensive patients, hypokalemia occurred in $4.9 \%$ patients of the aliskiren/HCTZ group versus $2.5 \%, 10.3 \%$ and $4.1 \%$ of patients treated with irbesartan/HCTZ, amlodipine/HCTZ or HCTZ alone, respectively [22].

\section{DISCUSSION}

SPCs of aliskiren/HCTZ has recently been introduced in European Union for the second-line treatment of adults with essential hypertension whose BP is not adequately controlled with either drug alone, or as a substitution treatment in patients with hypertension adequately treated by the two individual drugs concomitantly at the equivalent fixed dosage. To our knowledge, this study represents the first published meta-analytical approach to the efficacy of aliskiren/HCTZ in reducing BP in patients with mild to moderate hypertension. Although other reviews dealing with the same topic are available in the literature, no study has provided a synthesis of data from clinical trials.

The five studies included in this systematic review are short-term (8-12 weeks) randomized, double-blind, clinical trials with a similar design and comparable primary endpoints and secondary efficacy measures. All studies compared the change in SBP and DBP from baseline (start of double-blind treatment) to week 8 endpoint in each aliskiren/HCTZ combination group with that in placebo and/or aliskiren monotherapy and/or HCTZ monotherapy group. Patient demographics and baseline characteristics were also similar across treatment groups in all included studies, except that one study included obese patients only [22]. The average quality of the articles was considered to be very good.

In this study we chose to present the results by way of weighted average sums of BP reductions over 8 weeks, a period consistent with current clinical recommendations for 
assessing the clinical efficacy and tolerability of antihypertensive drugs following their initiation $[1,4]$. The weighted means method, which has been used in other meta-analyses [25-27], takes into account the different sizes of trials and provides results that are easy to interpret clinically.

In all clinical trials selected for analysis, commercially available aliskiren/HCTZ combinations (150/12.5 mg, $150 / 25 \mathrm{mg}, 300 / 12.5 \mathrm{mg}$ and $300 / 25 \mathrm{mg}$ ) provided clinically significant additional SBP and DBP reductions and improved BP control rates over aliskiren or HCTZ monotherapy, which demonstrates that aliskiren/HCTZ SPCs are a effective treatment option for patients with mild to moderate hypertension who do not achieve BP control with aliskiren $300 \mathrm{mg}$ or HCTZ $25 \mathrm{mg}$ alone. A meta-analysis of 354 randomized clinical trials involving more than 40,000 treated patients with hypertension revealed that the additional reduction in BP achieved with antihypertensive combination therapy versus monotherapy provide a reduced risk of stroke and ischemic heart events [28]. In another meta-analysis, examining individual data from one million adults in 61 prospective studies, it was found that, at ages 40-69 years, each increase of $20 \mathrm{~mm} \mathrm{Hg}$ usual SBP (or, approximately equivalently, $10 \mathrm{~mm} \mathrm{Hg}$ usual DBP) is associated with more than a twofold difference in the stroke death rate, and with twofold differences in the death rates from ischaemic heart disease and from other vascular causes [29]. Thus, the additional mean BP reductions of up to $8.0 / 4.8 \mathrm{mmHg}$ (versus HCTZ $25 \mathrm{mg}$ ) or $6.0 / 3.1 \mathrm{mmHg}$ (versus aliskiren $300 \mathrm{mg}$ ) provided by aliskiren/HCTZ $300 / 25 \mathrm{mg}$ in the present analysis might be expected to reduce the risk of cardiovascular mortality. However, long-term and large-scale studies analysing the effects of aliskiren/HCTZ combination therapy on clinical outcomes are required to confirm this hypothesis.

The capacity of aliskiren to enhance the antihypertensive efficacy of HCTZ reflects its complementary mode of action, targeting the RAS at its point of activation and thus suppressing PRA. HCTZ monotherapy increased PRA, as a result of stimulated renin release in response to reduced intravascular volume. The addition of aliskiren counteracted this effect, resulting in a significant ( $\mathrm{p}<0.05$ ) overall decrease in PRA compared with HCTZ monotherapy [21, 22, 24]. Furthermore, aliskiren effectively inhibited the renin enzyme, despite marked elevation in PRC, to produce an overall reduction in PRA from baseline. This contrasts to agents that block the RAS at other points, such as ACEIs and ARBs, which induce increases in PRA in parallel with PRC $[22,24,30]$.

Aliskiren/HCTZ was generally well tolerated in the clinical trials reviewed and not associated with a notably higher incidence of adverse events than treatment with either component alone. These results are consistent with a long-term open-label study in 1955 hypertensive patients showing that aliskiren/HCTZ free combinations were well tolerated over up to 12 months of treatment $[16,19]$. In three included trials, when aliskiren and HCTZ were administered in combination, aliskiren opposed the adverse hypokalaemic effects of HCTZ $[21,23,24]$. The safety profile of an aliskiren/valsartan/ HCTZ combination was also investigated in one clinical trial and was similar to the 2-drug combinations (aliskiren/HCTZ or valsartan/HCTZ), with a greater BP-lowering effect in patients not adequately responding to HCTZ monotherapy [24].

Most patients with hypertension will require combination treatment with two or more antihypertensive medications in order to achieve BP control to recommended levels $[1,4]$. A meta-analysis of adherence studies showed that the use of SPC regimens reduced the rate of non-compliance by 24 $26 \%$ compared with respective free combinations [31]. Aliskiren/HCTZ SPCs therefore offers the convenience of a single-tablet once daily treatment regimen, which may improve treatment compliance and subsequent BP control.

The limitations of this study should be noted. The intervention effect size as reported above (Tables $\mathbf{2}$ and $\mathbf{3}$ ) could be an overestimate due to publication bias since the manufacturer (Novartis Pharmaceuticals Corporation) sponsored four [20, 22-24] of the included published studies and one author of the remaining study [21] is employee of Novartis Pharmaceuticals Corporation. It is possible that less optimistic studies have not been published and therefore not included in our analysis. In addition, because the BP lowering efficacy estimate is limited to 8 weeks, we cannot extrapolate our results to the longer term benefits of the treatments on cardiovascular morbidity and mortality. However, in this regard, the 2007 European Society of Hypertension (ESH)/ European Society of Cardiology (ESC) guidelines are pertinent, which state that the size of $\mathrm{BP}$ reduction is more important than the class used for cardiovascular event reduction [4]. One other limitation is based on the fact that there is only one clinical trial investigating the antihypertensive efficacy of the lowest dose of aliskiren/HCTZ commercially available (150/12.5 mg), which, additionally, lacks information on outcome variability (SEM or CI) [21]. This fact was responsible for an unexpected higher efficacy of aliskiren/HCTZ 150/12.5 $\mathrm{mg}$ in reducing SBP and DBP, when compared with higher combination dosages (Table 3). Further studies are required to accurately evaluate the doserelated antihypertensive efficacy of the commercially available aliskiren/HCTZ combinations.

In conclusion, aliskiren/HCTZ combinations commercially available were effective and generally well tolerated in clinical trials evaluating its antihypertensive effects in adults with mild to moderate hypertension and in hypertensive patients with obesity, providing clinically significant additional $\mathrm{BP}$ reductions and improved $\mathrm{BP}$ control rates in patients who are inadequately controlled with aliskiren or HCTZ monotherapy. The aliskiren/HCTZ SPCs present the convenience of a once-daily single-tablet treatment regimen, which may improve treatment adherence and subsequent BP control. Further studies are required to evaluate the relative benefits of the aliskiren/HCTZ SPCs with generically available alternatives. Also, long-term trials evaluating the efficacy and tolerability of this combination therapy would be of interest to establish the ultimate effects of treatment on the cardiovascular morbidity and mortality of hypertension.

\section{ACKNOWLEDGEMENTS}

We thank the Fundação para a Ciência e a Tecnologia (FCT) for supporting the fellowship grant SFRH/BD/36756/ 2007 to Manuel Morgado. 


\section{APPENDIX}

Main Patient Baseline and Demographic Characteristics by Treatment Group of the Included Clinical Trials (Randomized Population)

\begin{tabular}{|c|c|c|c|c|c|c|c|c|}
\hline Reference & Pts., $n$ & Treatment and Daily Dose (mg) & $\begin{array}{l}\text { Patient Age } \\
\text { (years) }\end{array}$ & $\begin{array}{l}\text { Sex Ratio } \\
(\mathbf{M} / \mathbf{F})\end{array}$ & $\begin{array}{l}\text { BMI } \\
\left(\mathbf{k g} / \mathbf{m}^{2}\right)\end{array}$ & $\begin{array}{l}\text { Obese }(\text { BMI } \geq \\
\left.30 \mathrm{~kg} / \mathrm{m}^{2}\right)(\%)\end{array}$ & $\begin{array}{l}\text { SBP Baseline } \\
(\mathrm{mm} \mathrm{Hg})\end{array}$ & $\begin{array}{l}\text { DBP Baseline } \\
\text { (mm Hg) }\end{array}$ \\
\hline \multirow{15}{*}{$\begin{array}{l}\text { Villamil } \\
\text { (2007) [21] }\end{array}$} & 195 & Placebo & 54.4 & $109 / 86$ & NR & 40.5 & 152.7 & 99.3 \\
\hline & 184 & Aliskiren 75 & 55.0 & $103 / 81$ & NR & 41.8 & 153.2 & 99.4 \\
\hline & 185 & Aliskiren 150 & 53.5 & $112 / 73$ & NR & 32.4 & 153.4 & 98.8 \\
\hline & 183 & Aliskiren 300 & 54.2 & $99 / 84$ & NR & 38.8 & 154.4 & 99.3 \\
\hline & 194 & HCTZ 6.25 & 55.2 & $109 / 85$ & $\mathrm{NR}$ & 41.2 & 153.4 & 99.3 \\
\hline & 188 & HCTZ 12.5 & 55.4 & $103 / 85$ & NR & 38.8 & 153.4 & 99.1 \\
\hline & 176 & HCTZ 25 & 55.1 & $92 / 84$ & NR & 32.4 & 154.5 & 99.1 \\
\hline & 188 & Aliskiren/HCTZ 75/6.25 & 55.1 & $108 / 80$ & NR & 37.8 & 154.5 & 98.9 \\
\hline & 193 & Aliskiren/HCTZ 75/12.5 & 54.4 & $101 / 92$ & NR & 39.9 & 154.0 & 100.0 \\
\hline & 186 & Aliskiren/HCTZ 75/25 & 54.7 & $101 / 85$ & $\mathrm{NR}$ & 38.7 & 152.9 & 99.0 \\
\hline & 176 & Aliskiren/HCTZ 150/6.25 & 53.9 & $96 / 80$ & NR & 37.5 & 153.3 & 99.0 \\
\hline & 186 & Aliskiren/HCTZ 150/12.5 & 54.7 & $98 / 88$ & NR & 35.5 & 154.1 & 99.1 \\
\hline & 188 & Aliskiren/HCTZ 150/25 & 53.7 & $104 / 84$ & NR & 37.8 & 153.2 & 98.4 \\
\hline & 181 & Aliskiren/HCTZ 300/12.5 & 55.5 & $89 / 92$ & NR & 42.0 & 153.2 & 99.5 \\
\hline & 173 & Aliskiren/HCTZ 300/25 & 54.8 & $98 / 75$ & NR & 41.0 & 154.6 & 99.3 \\
\hline \multirow{4}{*}{$\begin{array}{l}\text { Jordan } \\
\text { (2007) [22] }\end{array}$} & 122 & HCTZ 25 & $55.2 \pm 12.3$ & $52 / 70$ & $34.0 \pm 4.1$ & NR & $149.5 \pm 11.3$ & $97.2 \pm 4.6$ \\
\hline & 122 & Aliskiren/HCTZ 300/25 & $53.1 \pm 11.9$ & $60 / 62$ & $34.8 \pm 5.2$ & $\mathrm{NR}$ & $149.4 \pm 11.6$ & $96.8 \pm 4.9$ \\
\hline & 119 & Irbesartan/HCTZ 300/25 & $53.0 \pm 11.0$ & $48 / 71$ & $34.3 \pm 4.7$ & NR & $149.1 \pm 13.4$ & $96.6 \pm 4.4$ \\
\hline & 126 & Amlodipine/HCTZ 10/25 & $55.2 \pm 11.9$ & $53 / 73$ & $34.5 \pm 4.1$ & NR & $149.8 \pm 11.5$ & $96.7 \pm 5.0$ \\
\hline \multirow{3}{*}{$\begin{array}{l}\text { Nickenig } \\
\text { (2008) [20] }\end{array}$} & 298 & Aliskiren 300 & $55.5 \pm 10.6$ & $159 / 139$ & $29.2 \pm 4.5$ & NR & $149.8 \pm 12.6$ & $95.5 \pm 4.4$ \\
\hline & 293 & Aliskiren/HCTZ 300/12.5 & $54.9 \pm 10.5$ & $155 / 138$ & $29.2 \pm 4.9$ & NR & $150.3 \pm 12.5$ & $95.5 \pm 4.3$ \\
\hline & 289 & Aliskiren/HCTZ 300/25 & $54.4 \pm 10.3$ & $172 / 117$ & $28.9 \pm 4.6$ & NR & $150.8 \pm 12.8$ & $95.8 \pm 4.7$ \\
\hline \multirow{3}{*}{$\begin{array}{l}\text { Blumen- } \\
\text { stein (2009) } \\
{[23]}\end{array}$} & 246 & HCTZ 25 mg & $52.9 \pm 11.5$ & $143 / 103$ & $29.7 \pm 5.0$ & NR & $151.8 \pm 11.9$ & $96.3 \pm 4.9$ \\
\hline & 244 & Aliskiren/HCTZ 150/25 & $53.6 \pm 11.1$ & $144 / 100$ & $28.9 \pm 4.7$ & NR & $151.2 \pm 12.7$ & $96.1 \pm 4.9$ \\
\hline & 232 & Aliskiren/HCTZ 300/25 & $54.1 \pm 9.5$ & $140 / 92$ & $29.9 \pm 5.0$ & NR & $151.1 \pm 12.3$ & $96.1 \pm 4.6$ \\
\hline \multirow{4}{*}{$\begin{array}{l}\text { Geiger } \\
(2009)[24]\end{array}$} & 152 & HCTZ 25 & $52.6 \pm 9.93$ & $94 / 58$ & $31.8 \pm 6.13$ & NR & $154.1 \pm 12.61$ & $99.9 \pm 4.33$ \\
\hline & 166 & Aliskiren/HCTZ 300/25 & $52.3 \pm 10.90$ & $92 / 74$ & $31.3 \pm 6.28$ & $\mathrm{NR}$ & $153.3 \pm 12.68$ & $99.3 \pm 4.10$ \\
\hline & 155 & Valsartan/HCTZ 320/25 & $55.0 \pm 11.40$ & $88 / 67$ & $31.3 \pm 5.85$ & NR & $156.7 \pm 12.49$ & $99.9 \pm 3.97$ \\
\hline & 168 & Aliskiren/Valsartan/HCTZ 300/320/25 & $52.9 \pm 10.83$ & $91 / 77$ & $31.9 \pm 6.21$ & NR & $152.7 \pm 11.64$ & $99.2 \pm 3.70$ \\
\hline
\end{tabular}

Values are mean \pm SD unless otherwise stated.

BMI - Body mass index; DBP - Diastolic blood pressure; F - Female; HCTZ - Hydrochlorothiazide; M - Male; NR - Not reported; Pts - Patients; SBP - Systolic blood pressure.

\section{REFERENCES}

[1] Chobanian AV, Bakris GL, Black HR, et al. Seventh report of the Joint National Committee on Prevention, Detection, Evaluation, and Treatment of High Blood Pressure. Hypertension 2003; 42: 1206-52

[2] Materson BJ, Reda DJ, Cushman WC, et al. Single-drug therapy for hypertension in men. A comparison of six antihypertensive agents with placebo. The Department of Veterans Affairs Cooperative Study Group on Antihypertensive Agents. N Engl J Med 1993; 328: 914-21.

[3] Cushman WC, Ford CE, Cutler JA, et al. Success and predictors of blood pressure control in diverse North American settings: the an- tihypertensive and lipid-lowering treatment to prevent heart attack trial (ALLHAT). J Clin Hypertens (Greenwich) 2002; 4: 393-404.

[4] Mancia G, De Backer G, Dominiczak A, et al. 2007 Guidelines for the Management of Arterial Hypertension: The Task Force for the Management of Arterial Hypertension of the European Society of Hypertension (ESH) and of the European Society of Cardiology (ESC). J Hypertens 2007; 25: 1105-87.

[5] Musini VM, Fortin PM, Bassett K, Wright JM. Blood pressure lowering efficacy of renin inhibitors for primary hypertension: a Cochrane systematic review. J Hum Hypertens 2009; 23: 495502.

[6] Baldwin CM, Plosker GL. Aliskiren/hydrochlorothiazide combination: in mild to moderate hypertension. Drugs 2009; 69: 833-41. 
[7] Chrysant SG. Aliskiren-hydrochlorothiazide combination for the treatment of hypertension. Expert Rev Cardiovasc Ther 2008; 6: 305-14.

[8] Jadad AR, Moore RA, Carroll D, et al. Assessing the quality of reports of randomized clinical trials: is blinding necessary? Control Clin Trials 1996; 17: 1-12.

[9] Moher D, Cook DJ, Eastwood S, Olkin I, Rennie D, Stroup DF. Improving the quality of reports of meta-analyses of randomised controlled trials: the QUOROM statement. Quality of Reporting of Meta-analyses. Lancet 1999; 354: 1896-900.

[10] Andersen K, Weinberger MH, Constance CM, et al. Comparative effects of aliskiren-based and ramipril-based therapy on the renin system during long-term (6 months) treatment and withdrawal in patients with hypertension. J Renin Angiotensin Aldosterone Syst 2009; 10: 157-67.

[11] Andersen K, Weinberger MH, Egan B, et al. Comparative efficacy and safety of aliskiren, an oral direct renin inhibitor, and ramipril in hypertension: a 6-month, randomized, double-blind trial. J Hypertens 2008; 26: 589-99.

[12] O'Brien E, Barton J, Nussberger J, et al. Aliskiren reduces blood pressure and suppresses plasma renin activity in combination with a thiazide diuretic, an angiotensin-converting enzyme inhibitor, or an angiotensin receptor blocker. Hypertension 2007; 49: 276-84.

[13] Littlejohn TW, 3rd, Trenkwalder P, Hollanders G, Zhao Y, Liao W. Long-term safety, tolerability and efficacy of combination therapy with aliskiren and amlodipine in patients with hypertension. Curr Med Res Opin 2009; 25: 951-9.

[14] Chrysant SG, Murray AV, Hoppe UC, et al. Long-term safety, tolerability and efficacy of aliskiren in combination with valsartan in patients with hypertension: a 6-month interim analysis. Curr Med Res Opin 2008; 24: 1039-47.

[15] Strasser RH, Puig JG, Farsang C, Croket M, Li J, van Ingen H. A comparison of the tolerability of the direct renin inhibitor aliskiren and lisinopril in patients with severe hypertension. J Hum Hypertens 2007; 21: 780-7.

[16] Gradman AH, Kolloch RE, Meyers M, et al. Aliskiren in combination with hydrochlorothiazide is effective and well tolerated during long-term treatment of hypertension [abstract no. P-384]. J Clin Hypertens (Greenwich) 2007; 9: 160.

[17] Calhoun DA, Villamil AS, Chrysant SG, et al. Antihypertensive efficacy of aliskiren/hydrochlorothiazide (HCT) combinations in patients with stage 2 hypertension: subgroup analysis of a randomized, double-blind, factorial trial [abstract no. P-209]. Hypertension 2008; 52: e97.

[18] Prescott MF, Boye SW, Le Breton S, et al. Antihypertensive efficacy of the direct renin inhibitor when added to hydrochlorothiazide treatment in patients with extreme obesity and hypertension [abstract no. 1014-169]. J Am Coll Cardiol 2007; 49: 370.
[19] Sica D, Gradman A, Lederballe O, et al. Aliskiren, a novel renin inhibitor, is well tolerated and has sustained BP-lowering effects alone or in combination with HCTZ during long-term (52 weeks) treatment of hypertension [abstract no. P-797]. Eur Heart J 2006; 27: 121.

[20] Nickenig G, Simanenkov V, Lembo G, et al. Efficacy of aliskiren/hydrochlorothiazide single-pill combinations in aliskiren non-responders. Blood Press 2008; 17(Suppl 2): 31-40.

[21] Villamil A, Chrysant SG, Calhoun D, et al. Renin inhibition with aliskiren provides additive antihypertensive efficacy when used in combination with hydrochlorothiazide. J Hypertens 2007 ; 25 : 217 26.

[22] Jordan J, Engeli S, Boye SW, Le Breton S, Keefe DL. Direct Renin inhibition with aliskiren in obese patients with arterial hypertension. Hypertension 2007; 49: 1047-55.

[23] Blumenstein M, Romaszko J, Calderon A, et al. Antihypertensive efficacy and tolerability of aliskiren/hydrochlorothiazide (HCT) single-pill combinations in patients who are non-responsive to HCT $25 \mathrm{mg}$ alone. Curr Med Res Opin 2009; 25: 903-10.

[24] Geiger H, Barranco E, Gorostidi M, et al. Combination therapy with various combinations of aliskiren, valsartan, and hydrochlorothiazide in hypertensive patients not adequately responsive to hydrochlorothiazide alone. J Clin Hypertens (Greenwich) 2009; 11: 324-32.

[25] Conlin PR, Spence JD, Williams B, et al. Angiotensin II antagonists for hypertension: are there differences in efficacy? Am J Hypertens 2000; 13: 418-26.

[26] Baguet JP, Robitail S, Boyer L, Debensason D, Auquier P. A metaanalytical approach to the efficacy of antihypertensive drugs in reducing blood pressure. Am J Cardiovasc Drugs 2005; 5: 131-40.

[27] Baguet JP, Legallicier B, Auquier P, Robitail S. Updated metaanalytical approach to the efficacy of antihypertensive drugs in reducing blood pressure. Clin Drug Investig 2007; 27: 735-53.

[28] Law MR, Wald NJ, Morris JK, Jordan RE. Value of low dose combination treatment with blood pressure lowering drugs: analysis of 354 randomised trials. BMJ 2003; 326: 1427.

[29] Lewington S, Clarke R, Qizilbash N, Peto R, Collins R. Agespecific relevance of usual blood pressure to vascular mortality: a meta-analysis of individual data for one million adults in 61 prospective studies. Lancet 2002; 360: 1903-13.

[30] Nussberger J, Wuerzner G, Jensen C, Brunner HR. Angiotensin II suppression in humans by the orally active renin inhibitor Aliskiren (SPP100): comparison with enalapril. Hypertension 2002; 39: E18.

[31] Bangalore S, Kamalakkannan G, Parkar S, Messerli FH. Fixeddose combinations improve medication compliance: a metaanalysis. Am J Med 2007; 120: 713-9. 